\title{
A TURIZMUS TÉRSZERKEZETI HATÁSA A HATÁRRÉGIÓKBAN
}

\author{
Dr. PhD Székely Andrea ${ }^{1}$ \\ ${ }^{1}$ föiskolai docens, Szegedi Tudományegyetem Mérnőki Kar
}

\begin{abstract}
SUMMARY
The role and importance of cross-border regions is in the focus of scientific research for a long ago. The theory of spatial interactions of different actors is an issue of different scientific fields. From the practical side, the regional policy of the European Union has a wide set of instruments for these special - often periferic, underdeveloped, or even in capability for being pioneer of development areas. With long peace years and expansion of touristic flows, tourist regions models appeared in the tourism geography literature. However, only a few models of cross-border tourist regions are known, and surprisingly most of them are based on North American evidence. We summarize these results with special attention to European experiences and offer new interdisciplinary research areas.

Kulcsszavak: határon átnyúló régiók, turizmus, térszerkezet
\end{abstract}

\section{BEVEZETÉS}

A turizmus hatásainak feldolgozása folyamatos a vele foglalkozó szakemberek és tudományos kutatók szemszögéböl. Ezúttal a turizmus térszekezetre gyakorolt hatását követhetjük nyomon egy speciális területen, a nemzetközi határok mentén. Másrészt a határon átnyúló régiók kialakulása, szerepe már évszázados távlatban is foglalkoztatja a tudományos gondolkodást. Az Európai Unió regionális politikája különös figyelmet fordít ezekre a gyakran periférikus helyzetü, elmaradott; vagy éppen a helyzetből adódó lehetőségeket fokozottan kihasználó - területekre. A turisztikai régiók kutatása a nemzetközi turizmus világméretüvé válásával került a fókuszba, azonban a két terület integrált kutatása viszonylag kisszámú produktumban és szük szerzöi kör munkássága nyomán bontakozik ki. A tanulmány célja a meglévő eredmények áttekintése és rendszerezése.

\section{A HATÁRON ÁTNYÚLÓ RÉGIÓK}

A határon átnyúló régiók definícióját külföldi és hazai szakemberek többféleképpen értelmezik, van, aki elnevezéstanban egyszerüen határrégiónak nevezi, és van, aki határon átnyúló régiónak hívja. Munkánkban a teljesség igénye nélkül felsorolunk néhány definíciót, mely közelebb visz a határon átnyúló régió kérdésköréhez.

A határrégió egyik definíciója szerint „egy olyan szubnacionális terület, amelynek gazdasági és társadalmi életét közvetlenül és jelentősen befolyásolja egy nemzetközi határ közelsége" (Hansen, 1983).

A határrégiók tulajdonképpen a határ menti térségeket jelentik az államhatárok egyik vagy másik oldalán, míg a határon átnyúló régiók már az együttmüködés magasabb szintjét képviselik, amelynek a végső eredménye többek között az is lehet, hogy a határ mentén müködő gazdaság határon átnyúló gazdasággá válhat. (Ratti - Reichmann, 1993)

„A határrégió egy területi részegység és egy regionális rendszer, kiegészítve a határral és annak jellegzetességeivel." (Schmitt-Egner, P. 1998)

„A határon átnyúló régió egy a földrajzból, történelemböl, ökológiából, etnikai csoportokból, gazdasági lehetőségekből stb. származtatható potenciális régió, amelyet azonban a határ két oldalán uralkodó államok szuverenitása két részre oszt.” (Council of Europe, 2000.)

Hardi Tamás közelítése: A nyitott határok esetében nyílik a legtöbb lehetőség arra, hogy a korábban periférikus helyzetü területek gazdaságai összekapcsolódjanak. A határ két oldalának egyre szorosabbá váló együttmüködése azt eredményezheti, hogy a határ menti területek komparatív előnyeiket kihasználva, egymást támogatva fejlődhessenek, s periférikus 
jellegüket levetkőzhessék. Ebben a megközelitésben a határtérségek gazdasági fejlődését már nem a politikai intézményi különbségek, hanem a szomszédos területek komparatív előnyeinek kombinációi biztosítják (Hardi, 2000). A határok és a határ menti térségek együttmüködésének ebben a magasabb fázisában már nem határmenti térségekröl (border regions), hanem határon átnyúló térségekröl (transborder regions) lehet beszélni. (Hardi, 2000)

Abban mindegyik definíció megegyezik, hogy egy speciálisan lehatárolt területi egységröl van szó, amelyre szükségképpen hatással bír a határ. A határ hatása pedig az éppen aktuális funkciójától függ, azaz nyílt, zárt, vagy szürő típusú-e határ. (Ratti, 1993) A definíciók nem mindegyike említi, de legalább két szuverén állam területére kell, hogy essen a határon átnyúló régió. Az pedig már teljesen a kutató saját nézőpontjára van bízva, hogy milyen specialitásokat, hangsúlyokat, társadalmi-gazdasági, földrajzi tényezőket vesz számításba a határon átnyúló régió meghatározásakor és vizsgálatakor.

\section{TURISZTIKAI RÉGIÓ}

Már maga a régió elnevezés is megosztja a különböző tudományok művelöit annak tekintetében, hogy mit is nevezzen/nevezzünk régiónak. Így nem meglepö, hogy a turisztikai régió elnevezés is más-más gondolatokat ébreszt/ébreszthet a vele foglalkozók fejében. A tapasztalatok szerint azon országokban, ahol az ország bizonyos pontjain erős a turizmus, ott inkább foglalkoznak a turisztikai kérdésekkel (pl. Spanyolország, Franciaország), mint ott, ahol az ország életében ez nem játszik fontos szerepet. Azon országok, melyek valamilyen okból fontosnak tartják, fejlesztik a turizmusukat, ott a turisztikai régiók kialakítása, elnevezése, problémaköre is jobban elötérbe kerül.

A turizmus kutatói közül, mint már említettük, kevesen foglalkoznak a turizmus térbeli lehatárolásával. Akik inkább koncentrálnak erre, azok a világ vagy legalább egy kontinens turizmusával foglalkozó szakmai szervezetek. Vélhetően az lehet az oka ennek a ténynek, mert általános az a nézet, hogy a turizmus Földünk egészét érinti, s mint ilyen az egész Földet osztják fel valamiféle szempontrendszer szerint turisztikai nagytérségekre. A világ turizmusával foglalkozó nemzetközi szervezet a World Tourism Organisation (UNWTO) öt turisztikai nagyrégióra osztja Földünket: 1) Afrika 2) Amerika 3) Ázsia és a Csendes-óceáni térség 5) Európa. Hazánk jelenleg kilenc önálló turisztikai régiót számlál, melyek a következők: Észak-Magyarország, Tisza-tó, Észak-Alföld, Dél-Alföld, Budapest-KözépDunavidék, Közép-Dunántúl, Nyugat-Dunántúl, Dél-Dunántúl és Balaton turisztikai régiók.

$\mathrm{Az}$ idegenforgalmi régiókat és azok illetékességi területeit a 4/2000. (II.2.) Gazdasági Minisztérium rendelet határozta meg, amely az addigi nyolc régió helyett a jelenlegi kilenc turisztikai régió lehatárolását tartalmazza. A turisztikai régiók illetékességi területe eltér a meglévő közigazgatási egységek és az 1996. évi XXI. törvény által meghatározott statisztikaitervezési régiók illetékességi területétöl. A turisztikai régióktól ugyan eltérő, de statisztikai adatgyüjtésre létrejött egységek az üdülökörzetek, melyek már évtizedek óta jelen vannak a hazai statisztikákban. A külföldi turisták könnyebb desztinációválasztása érdekében a magyar hivatalos turisztikai régiók időnként idegen nyelven összevontan jelennek meg: pl. Dunántúl és Alföld.

A turizmussal foglalkozó magyar kutatók közül turisztikai régiók általános definiálását ez idáig még senki nem közölte tudományos munkáiban. A határ és turizmus témaköre Magyarországon 1950 és 1989 között, a rendszerváltás elött nem volt kutatható a kelet és nyugat-európai politikai rendszerek különbözősége miatt. A rendszerváltás után érzékelhetővé vált mindkét témának vizsgálata, de az elméleti alapozó munkák ezen idő alatt a világ más tájain, illetve Európa nyugati felén megszülettek. A nemzetközi szakirodalomban 1979-ben Matznetter (1979) világitott meg a turizmus és a határok között némi térszerkezeti 
kapcsolatrendszert. Három esetet különböztet meg, az első esetben a határvonal messze esik a turisztikai területektöl (a), a második esetben a határ egyik oldalán a turisztikai terület rá van épülve a határvonalra és csak ezen az oldalon létezik turizmus (b). A harmadik esetben a két turisztikai terület találkozik a határnál, vagy egybeolvad a két turisztikai terület. (c)

1. ábra: Határok és a turisztikai területek

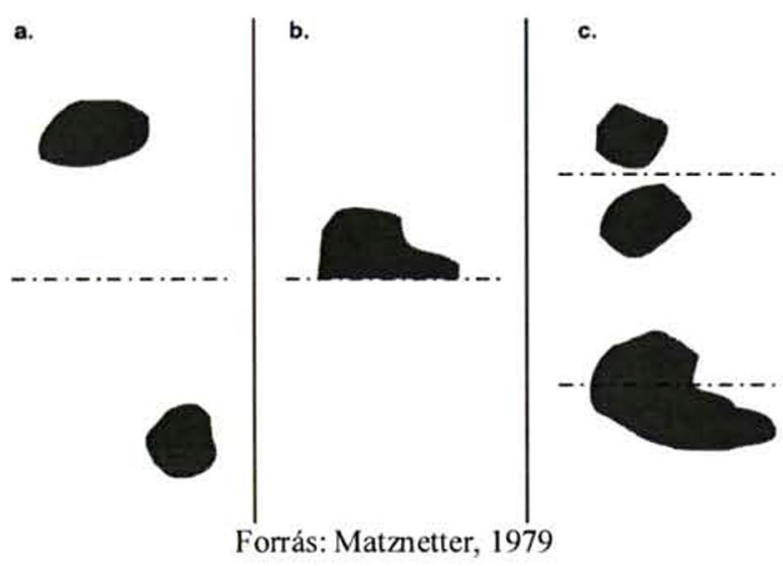

\section{HATÁRON ÁTNYÚLÓ TURISZTIKAI RÉGIÓK MODELLJE}

Egy lengyel kutató M. Wieckowski kutatásaiban 2011-ben funkciói alapján tipizálta a közép-európai határmenti turisztikai régiókat. 5 csoportot különböztet meg, nevezetesen:

1. (Természet)Védett területek turisztikai régió

2. Turisztikai sirégió

3. Tranzit turisztikai régió

4. Határmenti városok alkotta turisztikai régió

5. Multifunkcionális turisztikai régió

\section{1. (Természet) Védett területek turisztikai régió}

A határmenti régiók közül azok tartoznak ide, melyekben kifejezetten védik az ott található természeti környezetet (ilyenek például a Tátra, Pieniny- és Karkonosze hegységek területén fekvő nemzeti parkok Lengyelország, Csehország és Szlovákia határmenti területein). Az ilyen típusú Nemzeti Parkok turista paradicsomokká váltak, amiket az érintett országok nagy attrakcióként adnak el. Sok esetben a legfontosabb attrakció a nemzeti park, mint fö marketing elem/tényező. Más esetben a nemzeti parkok felkeresésének elsődleges oka annak egyedi karaktere. Ebben az összefüggésben a határ közelében levő nemzeti parknak lehetősége van a turisztikai régió fontos elemeként müködni mindkét szomszédos országban.

\section{Turisztikai sírégió}

Ez a típus összefüggő hegyvidéki területeken alakult ki. (pl. a Kárpátok Nyugati területén Zwardoń és Skalite-nél, a szlovák-lengyel határ közelében). Az ilyen típusú turista központok több síeléshez kapcsolódó szolgáltatással rendelkeznek (pl. sílift, sífelvonó), melyek határon átnyúló összeköttetést is biztosítanak. A határon átnyúló közös fellépés és közös üzemeltetésü sipályák kiemelten fontosnak számítanak. 


\section{Tranzit turisztikai régió}

Olyan köz,- és vasutak mentén szerveződő turisztikai régió, mely határ közelében található. Ezt a típusú turisztikai régiót az emberek határátlépésből eredő folyamatos áramlása élteti. A (még meglevő, de a schengeni belső határrá válás óta már nem müködő) határátkelő mellett sok más egyéb létesítményt is létrehoztak: hotelek, motelek, éttermek, pénzváltóhelyek, benzinkutak, rekreációra alkalmas területek.

Az érintett közép-kelet európai országok kiépitett határátkelö pontjainak épületei, sorompói az EU belső határává történő átsoroláskor elveszitették korábbi ellenőrző funkcióikat. Az áraktól és egyéb tényezőktől függöen ez a típusú régió a határ mindkét oldalán tud müködni valamint kapcsolatban állhat a legközelebbi városokkal vagy turista központokkal. (Pl. Cieszyn a csehlengyel határon, Zgorzelec-Görlitz vagy Słubice-Frankfurt a német-lengyel határon; ChyżneTrstena a lengyel-szlovák határon)

\section{Határmenti városok alkotta turisztikai régió}

Abban az esetben beszélünk erről a típusról, amikor határ(vonal) választ szét városokat. A határnyitás folyamata lehetővé tette az emberek számára a könnyebb határátkelést. A határmenti városok vonzók a turisták számára több okból is: földrajzi helyzetük miatt, a tranzitlehetőségek miatt, kulturális központjaik és kulturális, történelmi örökségeik miatt. Egy ilyen város mind a szomszédos országból, mind harmadik országokból vonzanak turistákat. Továbbá, a városok a saját országokban is kialakítják saját turisztikai vonzáskörzetüket. A turisztikai régió fejlődése szempontjából előnyösebb, ha a városok tengerpart mentén vagy hegyekben találhatóak (mint például: Świnoujście - Ahlbeck a lengyel német határon).

\section{Multifunkcionális turisztikai régió}

A multifunkcionális határmenti turisztikai régió nagy területet fed le, és számos különféle turisztikai attrakcióval és létesítménnyel rendelkezik (pl. Karkonosze-, Tatra és Pieniny hegység fejlődő régiója a schengeni zóna új belső határán).

A szerző hangsúlyozza, hogy a fent emlitett tipológia funkcionalista elveket vall, tehát a régiók turizmusban betöltött szerepe szerint állít fel kategóriákat. Az öt megnevezett kategória ténylegesen létezik s számos példa hozható rájuk Közép-Európa területéről (a szerző szükös és ellenmondásos példáin jobbak is). Az első két kategória teljesen egyértelműen jelzi a turisztikai régió funkcióját. A tranzit turisztikai régió funkciója is egyértelmü, de a régiók ide történő besorolása már igen nehézkes. Nem könnyen különíthető el a következő, 4. csoport: a határmenti városok, mint attrakciók alkotta turisztikai régiótól. Ez a kategória nem veszi számításba a határ két oldalán levő városok szimmetriáját, aszimmetriáját (hány város fekszik és földrajzilag pontosan hol a nemzetközi határhoz képest, a városok méretét sem tisztázza). A városok egymáshoz és a határhoz történö földrajzi elhelyezkedésének vizsgálata tágithatná az eddigi kutatás szempontjait, s igy új dimenziókat nyithat meg a közép-európai határmenti és turisztikai térszerkezeti kutatásokban.

\section{5. ÖSSZEFOGLALÁS}

A turizmus és annak hatása egyértelmüen jelen van a határrégiókban. A határon átnyúló régiókról, amint az előzőekben bemutattuk számos definíció, továbbá empirikus kutatás született. Az Európai Unió regionális politikája szintén e térkategóriára koncentrálva épitette/épiti együttmüködési programjait. A tanulmány terjedelmi okok miatt nem kívánt a határmenti régióknak ezen aspektusára koncentrálni, inkább a turisztikai régiók definícióját, elemzéseit próbálta rendszerezni. Megállapítható, hogy a turisztikai régió egységes, tudományosan elfogadott definíciója még nem született meg sem nemzetközi, sem hazai 
viszonylatban. A nemzetközi kutatások közül a határmenti turisztikai régiók modellezésére koncentrál a dolgozat egy közép-európai ország, Lengyelország példáján és Wieckowski munkáján keresztül. A javasolt funkcionális határmenti turisztikai régiótípusok bár néhol még összemosódottak, de jó alapot szolgáltatnak a további finomításoknak. A modell azért is örvendetes, mert európai, azon belül is közép-kelet-európai példákkal alátámasztható.

A határon átnyúló turisztikai régiók kérdésköre aktuális és igen izgalmas kihívásokat tartogat a regionális és turisztikai kutatásokat végző kutatók és szakemberek számára. Sok nyitott kérdés maradt még megválaszolatlanul, amelyeket interdiszciplináris együttmüködésben lehet megfelelően kutatni.

\section{IRODALOMJEGYZÉK}

Council of Europe (2000): Handbook on Transfrontier Co-operation for Local and Regional Authorities in Europe. Council of Europe, Genf.

Fehérvölgyi B. (2010): Határtalan lehetōségek a határ mentén. Doktori értekezés. Pannon Egyetem, Gazdálkodás- és Szervezéstudományok Doktori Iskola, Veszprém

Hansen, N. (1983): International Cooperation in Border Regions: an Overview and Research Agenda. International Regional Science Review. vol. 8, no. 3, pp. 255-270.

Hardi, T.(2000): Államhatárok és regionális együttmüködések In: Horváth Gy,. Rechnitzer J. (szerk): Magyarország területi szerkezete és folyamatai az ezredfordulón.. MTA Regionális Kutatások Központja, Pécs. pp. 595-615.

Matmetter J. (1979): Border and Tourism : Foundamental relations, In: Gruber G., Lamping H (eds): Tourism and Borders: Proceedings of the Meetong of the IGU Working Group - Geography of Tourism and Recreation, Institut fur Wirtschafts- und Sozialgeographie der Johann Wolfgang Goethe Universitat, Frankfurt, pp. 61-73.

Ratti R. - Reichman, S. (1993): Theory and practice of transborder cooperation. Helbing\&Lichtenhahn, Basel.

Schmidt-Egner, P. - Brunn, G. (1998): Grenzüberschreitende Zusammenarbeit in Europa. Theorie, Empirie, Praxis. Nomos, Baden-Baden.

http://itthon.hu/szakmai-oldalak/turizmus-magyarorszagon-080515-1/turizmus-magyaro-2008091123-1 